\title{
Development of a Settlement on the North-Eastern Promontory at 'Marea'
}

\author{
T. Derda, ${ }^{1}$ M. Gwiazda, ${ }^{2}$ A. Pawlikowska-Gwiazda ${ }^{3}$
}

\begin{abstract}
Excavations in 'Marea' in 2018 were conducted within a broader project, the aim of which was to recognize the ancient topography of this settlement. The work this season was mainly carried out at the promontory in the north-eastern part of the site with some partially visible buildings along an ancient street. The goal was threefold: to define when they had been built, for how long they had been in use and to verify results from the previous survey. Consequently, six trenches were made to gain material essential to date the aforementioned constructions. The oldest remains turned out to be from the Roman period, when this area became a rubbish dump for production wastes from adjacent pottery kilns. Above the heaps mainly made of amphorae AE 3 and AE 4 sherds, two occupation levels were recognised with the older one beginning in 3rd century or later. Unfortunately function of the structures uncovered at this level is still unclear. The consecutive phase can be dated to 5th-6th century. During that time buildings were constructed according to the regular grid which fits into the overall plan of the town. Executed works led to better understanding of the particular changes that occurred in this part of 'Marea'.
\end{abstract}

Keywords: Marea, Egypt, Roman period, early Byzantine period, early Islamic period, latrine, pottery, urbanism, streets, church

Dates of work: The nineteenth season of activities at 'Marea' lasted from 14 October-15 November 2018.

\section{Team:}

Director: Prof. T. Derda (Institute of Archaeology, University of Warsaw)

Field director: Dr M. Gwiazda (Institute of Archaeology, University of Warsaw)

Archaeologist: A. Pawlikowska-Gwiazda (Institute of Archaeology, University of Warsaw)

Glass specialist: R. Kucharczyk (Polish Centre of Mediterranean Archaeology, University of Warsaw)

Ceramologist: K. Danys (Polish Centre of Mediterranean Archaeology, University of Warsaw)

Ceramologist assistant: J. Faucher (not affiliated)

Architect: A. Kutiak (not affiliated)

Student: T. Groszek (Institute of Archaeology, University of Warsaw)

Inspectors: Walaa Mokhtar Rushdie, Ahmed Ali Hassan, Amr Ibrahim Ali.

\footnotetext{
${ }^{1}$ Institute of Archaeology, University of Warsaw, Krakowskie Przedmieście 26/28, PL - 00-927 Warszawa, t.derda@uw.edu.pl

${ }^{2}$ Polish Centre of Mediterranean Archaeology, University of Warsaw, Nowy Świat 4, PL - 00-497 Warszawa, mariusz.gwiazda@gmail.com

${ }^{3}$ Institute of Archaeology, University of Warsaw, Krakowskie Przedmieście 26/28, PL - 00-927 Warszawa, az.pawlikowska@uw.edu.pl
} 
Acknowledgements: Special thanks are due to Nashwa Gaber General Director of Foreign and Egyptian mission Affairs and Permanent Committee of the Supreme Council of Antiquities for her understanding of the work of the Mission and her special consideration. The excavations were financed by the National Science Centre (UMO-2017/25/B/H3/01841).

\section{Introduction}

The settlement known as 'Marea' is located on the southern shore of the Lake Mareotis (currently Lake Mariout), c. $40 \mathrm{~km}$ to the south-west from Alexandria. ${ }^{4}$ This place was first inhabited in the Hellenistic Period and continued to be so after the Arab Conquest (until $8^{\text {th }}$ century) (Pichot 2010). In the season 2018 works were concentrated mainly in the area to the east from the early Byzantine Great Basilica, where six different trenches were dug [Fig. 1]. ${ }^{5}$ Two of them (trench S1-1 and S12) were made primarily to confirm existence of a street running northwards just behind the apse of the Great Basilica, whereas the remaining four further to the east and north (S3-1, S4, S5, L1) were supposed to help dating the surrounding buildings. Another goal was to analyse stratification below the foundations of the structures visible on the surface (trenches S-1, S1-2 and S3) leading to the better understanding of the landform and earlier architecture.

The preceding excavations in the aforementioned sector had uncovered the house $\mathrm{H} 1$, latrines L1 and a quay (Babraj et alii 2013: 67-73; Babraj, Drzymuchowska, Willburger 2014: 48-52; Wielgosz, Gwiazda 2016, Gwiazda and Pawlikowska-Gwiazda in this volume). Tops of the walls clearly visible on the surface had also been previously documented (Kościuk 2012). Summing up, the intention of mission 2018 was to widen our perspective and to increase our knowledge about this part of 'Marea'.

\section{Results}

\section{Trench S1-1}

Trench S1-1, measuring $2 \mathrm{~m}$ (north-south axis) by $5 \mathrm{~m}$ (east-west axis), is perpendicular to longer axis of the building S3. The first layer encountered here was silt, probably blown by the wind during the last phase of inhabitation and post-abandonment period. One ostracon was found in the deposit with the short, but complete trading-administrative text (dated to $7^{\text {th }}-8$ th century). Below there was a rubble composed of pseudo-ashlars and mortar fragments, both coming from the destroyed walls of the building S3 [Fig. 2], and some pieces of ceramic vessels (kitchenware,

\footnotetext{
${ }^{4}$ Ancient name "Marea" and its identification is further discussed in: Rodziewicz 2010; Wipszycka 2012.

${ }^{5}$ At the same time, mission from The Cracow Archaeological Musem was working within the Great Basilica. Third group of archaeologists was conducting magnetic survey and electrical resistivity tomography in the southern part of the settlement. Their results will be presented in the separate reports.
} 
tableware, amphorae, jugs). Thus, we may assume that this place was treated as a temporary rubbish dump.

After clearing this debris, a new wall, oriented east-west and adjacent to the building S3, was uncovered along the southern side of the trench [Fig. 3]. It was partially dismantled prior to the destruction of the building S3. In the eastern edge of the trench yet another wall was unearthed, but this time it was thinner and poorly preserved. It also enclosed a space measuring 1 by $1.5 \mathrm{~m}$ with the traces of simple mortar floor, creating a compartment of unknown purpose.

Below there was a consistent, thin $(0.1 \mathrm{~m})$ silt stratum covering the whole trench, mixed with pottery fragments (bowl, lid, amphorae LR 1, LR 4, LR 5/6, LR 7 and residual AE 3)( Pieri 2005: 69-84, 101-131; Dixneuf 2011: 97-134), broken glass, three coins, one iron nail and some animal bones. This deposit was the last belonging to the occupation phase, before the final destruction of the building S3. However, by the time it collapsed, upper rows of the western outer wall of that building had been dismantled. The remains of that wall were uncovered in the western edge of the trench, under a layer of silt.

The next deposit also suggested an intentional human activity. The debris was composed mostly of small-sized cobblers, among which the biggest ones measured $0.25 \mathrm{~m}$ x $0.2 \mathrm{~m}$ x $0.13 \mathrm{~m}$. Stones were mixed with mortar, pottery (jug, bowl, plate, amphorae LR 1 as well as numerous fragments of LR 5/6 and LR 7), glass vessels, an iron nail and one coin. Its southern boundary was marked by the dismantled wall running along the south baulk. The worst preserved west part of that wall was partially covered with the above described deposit. Being much thicker on the east side (c. $0.2 \mathrm{~m}$ ), the whole layer was slightly sloping down westwards until it vanished completely.

Contrary to our expectations, neither a stone pavement, nor a mortar floor was uncovered in the west part. However, we cannot exclude the possibility that they had been cleared away while dismantling the southern and western wall of the building S3. Nevertheless, only some tamped earth was found below.

Following its removal, a very regular and wide structure was unearthed, probably a foundation of the southern wall [Figs 3, 4]. Initially, it could have been an older construction, destroyed or dismantled at some point, and afterwards reused as a foundation. From the west it was adjoining perpendicularly the outer (western) wall of the building S3, which was in the same time the eastern boundary of the street running between the Great Basilica and the complex S3 (see below).

Beneath foundations of the building S3, in the central part of the trench, remains of two structures were encountered: mudbrick wall (S1-1-16) and stone wall or foundation (S1-1-22). The first one, made out of bricks measuring c. $0.4 \mathrm{~m} \mathrm{x} 0.2 \mathrm{~m} \mathrm{x} 0.7 \mathrm{~m}$ [see Fig. 4], was added later. It was oriented north-south and its overall width was c. $0.8 \mathrm{~m}$. Bricks were also visible underneath the foundation of the building S3. An older stone structure (S1-1-22) of the width $0.6 \mathrm{~m}$, partially covered with the mudbricks, was built using irregular limestones varying in size $(0.4 \mathrm{~m} \mathrm{x} 0.37 \mathrm{~m} \mathrm{x}$ $0.15 \mathrm{~m}$ to $0.20 \mathrm{~m} \times 0.1 \mathrm{~m} \times 0.09 \mathrm{~m}$ ) with no traces of mortar. The characteristic feature of this 
construction was that it did not fit into the former layout, since its orientation was not ideally northsouth, but it slightly leaned toward the west. Thus, it cannot be interpreted as a foundation of the mudbrick wall. Further west there was a concentration of the unworked limestones of different sizes (from $0.13 \mathrm{~m} \times 0.1 \mathrm{~m} \times 0.7 \mathrm{~m}$ to $0.42 \mathrm{~m} \times 0.33 \mathrm{~m} \times 0.2 \mathrm{~m}$ ), which were also clearly visible under the western outer wall of the building $\mathrm{S} 3$. The top of this deposit had $1.10 \mathrm{~m}$ (east-west axis) by $1 \mathrm{~m}$ (north-south axis). The collected data is still insufficient to rightly describe the meaning of this structures or to define the time of their construction.

\section{Trench $\mathrm{S1-2}$}

This trench is a direct extension of the previous one: it has the same width $(2 \mathrm{~m})$ and orientation, but it is much longer $(9.8 \mathrm{~m})$. Both trenches are separated from each other with a halfmeter baulk. North and south boundaries were artificially demarcated, contrary to the western edge which was limited by the apse and eastern wall of the Christian basilica [Fig. 5]. First and foremost, we had to clear away c. $2 \mathrm{~m}$ of modern debris, made during the former activity of the archaeologists from the Cracow mission. First undisturbed layer was identical to the silt sediment in the trench S1-1. It had some inclusions like pottery fragments (jug, lid, amphorae LR 1 and LR 5/6), an oil lamp, broken glass vessels, a small amount of animal bones and last but not least - fragment of a limestone game board [Fig. 6]. In the eastern part little limestone blocks and boulders were found, as a result of the natural gradual collapse of the neighbouring walls. When this deposit was finally removed, remains of a wall (S1-2-12) came to light. Traces of its destruction had been noticed earlier. The masonry was constructed with limestone pseudo-ashlars, the biggest of which measured $0.56 \mathrm{~m} \times 0.3 \mathrm{~m} \times 0.25 \mathrm{~m}$. Mortar was used as a bonding material, although it was not well preserved. The width of the wall was $0.5 \mathrm{~m}$ and it was laying on the foundation made of smaller unworked limestones (max. size $0.22 \mathrm{~m} \times 0.3 \mathrm{~m} \times 0.15 \mathrm{~m}$ ). This structure had a dual function - it was both an outer wall of the compartments located just behind the apse of the Great Basilica and a western boundary of above mentioned north-south street [Fig. 7]. The street itself was very simple - it was a level of tamp earth, significantly raising up towards the west. On its surface there was a layer of crushed mortar, much thicker in the west than in the east $(0.1 \mathrm{~m}$ to 0.5 $\mathrm{m})$. Mortar and plaster probably flaked off the face of the wall S1-2-12, hence the significant difference in thickness.

In the south-east corner of the trench, directly below the mortar deposit, we discovered a pit sunk into the street and filled almost entirely with ashes. Apart from that, burnt animal bones and fragmented ceramic vessels were found (amphoras LR 1, LR 5/6, bowls, jugs as well as residual AE 3 and AE4). Horizontal plan of the pit measured 1.1 by $0.88 \mathrm{~m}$, although it must have been bigger since it was clearly visible in the eastern and southern trench bulk. The considerable size of this feature suggests that it was probably a hearth used for a fairly long period. Layers on the street level included many sherds of amphorae LR 1, smaller amount of amphorae LR 5/6, plates, bowls, jugs, glass, animal bones and an oil lamp. Besides that, there were fragments of amphoras AE3 and AE 4 along with a separator used in kiln. Beneath, ginger red earthen deposit was found. Most 
probably it was a terracing fill, levelling up terrain for the construction of the Great Basilica and/or the building S3. It had an enormous number of amphoras AE 3 and AE 4 wasters. After the removal of this deposit, another wall was unearthed (S1-2-26) oriented north-south and built out of unworked limestones measuring up to $0.4 \mathrm{~m} \times 0.25 \mathrm{~m} \times 0.2 \mathrm{~m}$ [see Fig. 5]. The estimated width of the wall is $1.2 \mathrm{~m}$, although it cannot be confirmed as its west face was partially covered up with rubble. Yet there was no doubt that those scattered limestone cobblers originated from the wall, which at some point had collapsed.

To the west from the wall S1-2-12 we uncovered other structures. Adjacent both to the church apse and the abutment was a white mortar floor, enclosed from the east by another wall (S12-5). The masonry was quite typical - limestone pseudo-ashlars of maximum width $0.58 \mathrm{~m}$ and maximum height c. $0.4 \mathrm{~m}$. Mortar was again used as a bonding material. This wall was parallel to the wall S1-2-12 and, likewise, its orientation was north-south. It was built at distance of $2.2 \mathrm{~m}$ from the wall of the Basilica. This area had to be levelled up before laying the floor. Consequently, terracing layer was filled with residual amphoras $\mathrm{AE} 4$, separators used in the pottery kilns and much later pieces of amphoras LR 1 and LR 7. As a contrast, in the deposit above the mortar floor only two types of amphoras (LR 1 and LR5/6) were identified. We also found six coins, which will enabled estimating the time of abandonment of this part of the church.

Between the walls S1-2-12 and S1-2-5 another mortar pavement was discovered. It was buried under the sediment layer with fragments of pottery (amphorae LR 1 and LR 5/6), glass vessels and animal bones. Right below this mortar floor several examples of amphoras LR 1 and LR 7 as well as one coin from 5th-6th century CE were found. Furthermore, 0.20 m eastwards from the wall S1-2-5 we noticed additional structure, which was later interpreted as a badly preserved or intentionally dismantled wall (S1-2-19) [see Fig. 5]. Its orientation was the same as the orientation of the both aforementioned walls. In like manner it was composed of pseudo-ashlars measuring from $20 \mathrm{~m} \times 15 \mathrm{~m} \times 8 \mathrm{~m}$ to $38 \mathrm{~m} \times 30 \mathrm{~m} \times 20 \mathrm{~m}$ bonded with mortar. The top of the remaining wall was equal to the level of the mortar floor.

Further research was carried on in this section within three smaller trenches dug along the $\mathrm{S}$ baulk. The aim was to find foundations of the all uncovered walls. Eventually, layers from all trenches started to look alike (ginger red, wet, full of broken pieces of Roman amphora AE 3 and $\mathrm{AE} 4$ ). The trench S1-2 continued to be explored until the water level was reached.

\section{Trench S3-1}

Trench S3-1 was made to examine stratification under the building S3, thereby defining the time when it had been founded. This construction is limited by the Lake Mareotis from the north and the east. It also neighbours with the Great Basilica from the west and with the house H1 from the south. Trench was dug in the north-western part of the building, which had been formerly cleared in the previous seasons [Fig. 8] (Initial number of the room was 80, see Kościuk 2012: 32-34, fig. 2). The trench was enclosed by the eastern, western and southern walls, while its northern boundary was arbitrary outlined. It was almost square in plan: north-south axis measured $2 \mathrm{~m}$, and 
east-west axis $-2.32 \mathrm{~m}$. Exploration began with the removal of the limestone slabs belonging to the original pavement. The strata uncovered below were identified as a foundation of that floor and they included some pieces of amphoras (LR 1, LR 4) and residual fragments (AE 3, AE 4). The next layer was mainly composed of ashes and pottery sherds (AE3, AE 4, LR 1). Not only was it covering the whole trench, but it was filling two foundation ditches to the west and to the east [Fig. 9, S3-1-4]. This proves that both walls, eastern and western, were constructed in the same period. It is worth to mention that the southern wall of that room was not tied with the rest of the building.

The eastern foundation was c. $1.75 \mathrm{~m}$ deep measuring from the floor level. In the lower part it was filled with pseudo-ashlars and unworked limestones (max. size $0.15 \mathrm{~m} \mathrm{x} 0.13 \mathrm{~m} \mathrm{x} 0.7 \mathrm{~m}$ ). The upper part was composed of the same material, but this time it was bound with mortar. The foundation of the western wall was made similarly, although it was not so deep $(0.8 \mathrm{~m}$ below the level of the floor). The difference between these two walls was due to a natural downslope of the terrain towards the lake: the deeper foundation was supposed to prevent a catastrophe. Both foundation ditches were cut through several layers, which were probably deposited here to level up the ground. They were composed of slag, pottery fragments (LR 1, LR 5/6 with residuals sherds of AE 3 and AE 4), separators and a coin preliminarily dated to 5th-6th century.

In the excavated trench S3-1, below the level of the floor on the depth of c. $1.2 \mathrm{~m}$, we found numerous fragments of broken amphoras AE 3, AE 4 along with separators and bricks that had been used to build pottery kilns. Another characteristic component was a significant amount of black ashes. The lack of any other inclusions brought us to the conclusion that it was once a ceramic dump, made during the Roman period. Underneath there was a light brown silt layer, which had been an occupation level in the Roman times, before it was covered with production wastes. As the water level was reached, the exploration could not be continued henceforth.

\section{Trench $\mathrm{S4}$}

$1.5 \mathrm{~m}$ north of the latrine L1 and to the west from the lake, archaeological examination of an unidentified building was undertaken, focusing on its southern part. Sloping ground and, consequently, less strata covering the architectural structures were the reasons why this particular place was chosen for excavation. After partial unveiling of the tops of the walls on the southern side, it became possible to reconstruct the internal space organization of the building. There were at least two rooms there, as indicated by the presence of three foundation walls of north-south direction [Fig. 10]. Further works showed that the original occupation levels had been completely destroyed and thus only the foundations of the walls and the levelling layer between them survived. The building probably had a trapezoidal plan due to natural conditions of the surroundings. In addition, it was observed that the southern wall was continuing to the east, protruding before the face of the eastern wall. However, it was not possible to completely unearth this part of the structure as it had already been inundated. The foundations of the outer walls were made of ashlars, pseudoashlars and unworked limestones, arranged in rows, whereas the foundation of the inner wall was 
built exclusively with unworked limestone cobblers of maximum size $0.2 \mathrm{~m}$ x $0.16 \mathrm{~m}$ x $0.7 \mathrm{~m}$. The tops of both southern and eastern wall foundations were clearly sloping down towards the southeast corner, owing to the gradual subsidence of building (especially closer to the lake). Nonetheless, we cannot be certain if the downward movement of this terrain had already started during the occupation period, or was it merely a long term process continuing up to the modern times.

During the works, a trial pit was also made in the central part of the building in order to obtain some dating material. Fragments of amphorae LR 1 and LR 4 were found here, indicating that Building S4 was founded either in the 5th-6th century AD or later.

\section{Trench S5}

Building S5 was recognized to the north of the transept of the Great Basilica. The works were aimed at identifying the layout of the building and determining its chronology. Firstly, the cleaning works of the visible wall remains were undertaken. As a result, at least six separated compartments, varying in size, were identified [Fig. 11]. It is interesting that there were no door openings connecting particular parts (rooms) of the building.

The following stage of works was concentrated on cleaning two rooms (S5-1-2A and S5-12B) on the east side [see Fig. 11]. After removing the rubble coming from the disintegration of the walls, a floor made of limestone slabs was unveiled. It is possible that this level had been created during the last phases of the existence of the building, since it is higher than the other ones. A small amount of objects discovered in this room suggested that it had been intentionally emptied before the abandonment. The research in the second room resulted in uncovering several strata mainly composed of sediments mixed with numerous objects. There was no rubble that could have been associated with the destruction of the walls. Approximately 200 small bronze Byzantine coins were found in the south-eastern part of the room. Another important discovery in the room S5-1-2A was a partially exposed row of amphorae (LR 7?). It is located $1.5 \mathrm{~m}$ north from the southern wall of the room and extends westwards over a distance of at least $1.5 \mathrm{~m}$, however its west end has not been reached yet. Adjacent to the western wall, another concentration of artefacts was found (wellpreserved jugs, fragments of LR 1 amphora with dipinti, and clots of resin, possibly for impregnation of amphorae). Moreover, 6 ceramic artefacts identified as wick-holders were found within the room (cf. Foy 2011: 272-275, fig. 1,2). After careful examination of the findings, we can assume that Building S5 was used in the 6th-7th centuries AD, although we cannot exclude that it had been abandoned as late as the middle of the 8th century AD.

In the northern part of Building S5, a trial pit was opened in order to verify the hypothesis put forward some years ago by J. Kościuk about the presence of a portico in this place (Kościuk 2012: 35). During the works, a floor level was partially uncovered on the north side of the presumed portico. We also managed to clean one of the faces of the alleged stylobate. This allowed us to observe that the top of the column base is at the same height as the rest of the supposed stylobate. Therefore, the base was rather reused in this place, casting doubt on the supposition that this had been the support of a column. 


\section{Latrine L1}

Latrine L1 is located east of the house H1, just near the lakeshore. Excavations here were already carried out in 2012, revealing the structure almost entirely. The necessity to make an additional inventory of architectural remains encouraged us to recommence exploration in 2018.

After partial cleaning of the building, we identified some previously unexplored archaeological deposits. The first stratum was found in the sewage channel on the eastern side of L1-2 room and it was firstly interpreted as a construction element of the platform located in the middle of the building [Fig. 12]. The deposit in its upper part contained rubble of the wall collapsed after the final abandonment of the building. Below, the concentration of broken amphorae (LR 1, LR 4, LR 5/6, LR 7) and jugs was found, accumulated here when the latrine was still in use. The lower part of channels was filled with white silt.

While cleaning debris in the north-western part of the latrine, a water supply channel was discovered [see Fig. 12]. It was filled with a small amount of rubble, a large amount of silt and broken ceramic vessels (including amphorae LR 1, LR 4, LR 5/6, LR 7 and LRD dish (Hayes 1972: 382, form $9 \mathrm{~B}$, dated to c. $580 / 600$ to end of 7 th century).

Further works in this sector were undertaken eastwards of the latrine, on a (today's) narrow area between the building and the lake. After the removal of modern deposits, remains of a structure made of stone blocks were unearthed [see Fig. 12]. In two places, the structure was cut by channels carrying waste straight into the lake.

After the building had been thoroughly cleaned, one of the central 'platforms' (L1-2) serving as a walking level in the past was explored. The latrine seats made of blocks were originally placed on this 'platform', upper surface of which was covered with limestone paving. This level was partially removed in order to acquire a sample of material allowing to determine the time of building foundation. Directly under the floor, there was a brown-coloured layer containing lumps of mortar and broken limestone floor slabs. Within this layer, numerous fragments of LR 1 amphorae were found, and 5th-6th century coins, indicating terminus a quo of the building foundation. Another layer, $0.30 \mathrm{~m}$ below, was a deposit of mixed green, brown and yellow silty sediments. In addition to the LR 1 amphorae, there were also fragments of a Roman amphorae AE 4. This layer was not fully explored as the water level in the lake was too high.

\section{Discussion}

Among the discoveries in season 2018 the most noticeable were deposits connected with the functioning of the pottery kiln or kilns in the Roman Period 'Marea' (cf. Babraj, Kogut 2015). A great number of broken amphoras AE 3 and AE 4 were found. Moreover, bricks from the kiln's construction and separators used during the ceramic firing process were also present. Occasionally, we also encountered significant amount of ashes. Some pottery middens were located in the close

neighbourhood of the kiln (in the trench S1-2), whereas others were positioned $30 \mathrm{~m}$ further to 
north-east (in the trench S3-1). The previous mission had come across similar debris under the house H1 (Gwiazda and Pawlikowska-Gwiazda in this volume).

The next occupation level was constituted of unidentified structures built above the pottery middens. The foundations of the stone walls and a mudbrick wall in the trench S1-1 are the only remains visible today. Supposedly of the same age were a baptistery (4th or 5th century) and some mudbrick structures, which were discovered under the Great Basilica as a result of the earlier excavations (Szymańska, Babraj 2007: 57, 59-62, fig. 3, 4). In 2016 underneath the original pavements of the house $\mathrm{H} 1$ even more wall foundations were recognised, ones that may be also associated with the same phase. ${ }^{6}$

In the 5th-6th century (or slightly later) dismantling of the old walls was followed by the erection of some new buildings. Consequently, the ground had to be levelled up prior to the construction of the building S3, which is proved by many levelling layers found in the trench S31.

According to the preliminary observations by J. Kościuk, eastern wing of the building S3 was a later addition. This assumption was made only by examining the tops of the walls that were visible on the surface (Kościuk 2012: fig. 2). Recent results negate this theory - this part of the building was undoubtedly raised simultaneously with the central segment. Excavation in the trench S1-1 proved that in the west part there were an additional row of rooms [see Fig. 1]. Nevertheless, we cannot be positive whether they were added later or not. All in all, now it is certain that this architectural complex was much bigger (c. $22 \mathrm{~m}$ width) than it had been initially assumed and its western façade was in line with the outer face of the house H1.

To the east from the Great Basilica in the trench S1-2, terminus a quo of the two uncovered walls (S1-2-5 and S1-2-12) was determined to 5th-6th century. Both walls were parallel to the transept of the basilica. Discovery of the mortar floors between them confirmed existence of at least two rooms (S1-2A and S1-2B) [see Fig. 5], unfortunately with nothing inside to define their function. Hypothetically, if the wall S1-2-5 was to continue northwards, it would eventually meet with the apse, whereas wall S1-2-12 would join with the wall visible on the surface, c. $24 \mathrm{~m}$ far off (Kościuk 2012: fig. 2). Furthermore, the floor in the room S1-2A abutted the outer face of the apse, so probably these structures were somehow connected with each other. Neither of these discoveries, however, may unquestionably confirm that they were contemporary with the foundation time of Great Basilica. Nevertheless, such additional rooms near the apse are widely known from Abu Mena or other Christian sites in Egypt (Grossmann 2002).

On the earlier plans a street oriented north-south was already marked in the area between the Great Basilica and the building S3 (Kościuk 2012: fig. 2). Thanks to ongoing research we may now verify its form and size. By revealing the western outer wall of the building S3, total width of the street was measured, which is now c. $5 \mathrm{~m}$. Oddly enough, there was no paving nor drainage

\footnotetext{
${ }^{6}$ The result of this excavation are yet to be published. Personal observation.
} 
channel underneath. In 2017 to the west of the House H1, the same street was unearthed, yet this time it had a sewage system covered with limestone slabs (Gwaiazda and Pawlikowska-Gwiazda in this volume). It was shedding wastes from the north-west (where supposedly was another street running along the southern side of the Great Basilica) further south towards the lake. ${ }^{7}$

Cleaning latrine L1 completely allowed us to investigate this structure more carefully. Two platforms located to the south and to the north (L1-1 and L1-2) were adjoining the western wall of the latrine and from the three remaining sides they were surrounded with sewers [see Fig. 12]. Parallels from other archaeological sites present similar arrangements: one side of platforms abuts the wall, along the rest there are rows of seats with a canal below (Szymańska, Babraj 2008b: 35-38; Czerner 2016: 152, fig. 6; Grossmann 1977: 35-37, pl. 8a; Grossmann et alii 1991: 474-475). In the case of latrine L1 it seems that entrance or entrances were not on the western side, but directly opposite. No doorways in the eastern wall were found, but remains of the stairs on the east side justify this theory. The exterior part of stairs was built using limestone pseudo-ashlars, while interior was filled with soil. The closest analogy comes from the funerary chapel dated to 6th century in the southern part of 'Marea' (Babraj, Szymańska 2018: 177-178, fig. 65). This example stands strongly in favour of the interpretation that the entrance to the latrine was originally from the lakeside (Kościuk 2012: 34, fig. 2). However, it was only possible by using footbridge tying the highest step of the stairs with the platforms inside.

An interesting architectural element was found between the middle and southmost platform (L1-1, L1-2) - a collateral wall, dividing the whole latrine into two compartments of different sizes. Separating left side from the right side may be related with the gender division. This kind of adjustment is rather unique for latrines, though we have some analogies deriving from other types of public buildings. For instance, in the neighbouring southern baths (contemporary with the latrine L1) two independent sectors were created, one for males and other for females (Fournet, Redon 2017: 285, 307-309). ${ }^{8}$ Taking into account different examples of ancient latrines (Koloski-Ostrow 2011: 52), estimated number of people that could use structure L1 at the same time is approximately $18-25$. Thus, its purpose was definitely public rather than private.

Works in season 2018 also allowed to examine the sewage system within the latrine L1. A water canal, which served for washing down all excrements when needed, was running from outside into the north-west corner of the latrine, where it joined cloaca surrounding all three platforms (L1-1 to L1-3). The sewage mouth was on the opposite side as it is indicated by the lakeward direction of the channels conducted underneath the stairs.

\footnotetext{
${ }^{7}$ Sewage system had been already identified by the Egyptian mission in the northern part of 'Marea'. These channels were connected with the biapsidal bath complex, el-Fakharani 1983: 178-179, fig. 1, 2. ${ }^{8}$ It is also supposed that a latrine likewise divided according to sex, was located next to the hemicycle in Abu Mena, Grossmann et alii 1991: 474-475.
} 
Among the pottery findings within the sanitary sewer the most distinctive discoveries were big fragments of amphorae LR 5/6 and small jugs [Fig. 13]. ${ }^{9}$ Fresh water might have been stored in the bigger vessels, while more handy jugs were used for ablutions. Such jugs were rather multifunctional, especially if we take into consideration that they were found in different contexts all over the site. ${ }^{10}$ When latrine L1 was in use, lime had to be thrown on faeces to remove the unbearable smell (De Groot, Bernick-Greenberg 2012: 172). Its traces were noticed in a form of white sediment filling the sewer.

Ceramic sherds and coins found in the latrine L1 as well as in trenches S1-1, S1-2 and S5 demonstrate that 'Marea' was abandoned in late 7th-8th century as a result of a relatively long and gradual process. Dismantling the walls (like in the building S3) and then reusing acquired material was one of the typical features of this period. ${ }^{11}$ In the next stage abandoned places were turned to rubbish dumps, hence the animal bones and pottery pieces. After the last occupation phase the whole area was covered with natural deposits.

\section{Conclusions}

First and foremost, we have managed to distinguish three phases in the north-east sector of 'Marea'. The earliest one, so-called "kiln phase", had produced large pottery middens with amphoras $\mathrm{AE} 3$ and $\mathrm{AE} 4$ that had been fired on-site. The size of these deposits was quite impressive - their overall width was up to $30 \mathrm{~m}$ and they were at least $1.7 \mathrm{~m}$ thick. Consequently, the natural landscape had been significantly changed, which was relevant for later building activity. The walls of unknown purpose were the remains of the next phase, although not much can be said about this particular period. Still, chronological framework can be presented as follows: the end of amphora production in the 3rd century (terminus a quo) and building activity in the 5th-6th century or later (terminus ante quem). This is also the time when the well-planned quarter of diverse function raised, including the building S3 (harbour warehouse or shop), ${ }^{12}$ latrines, the Great Basilica and the house H1. In the previous season a deposit of ostraca adjacent to the wall of the latter dwelling was discovered, which is considered to be a part of "building corporation" archive (Babraj, Drzymuchowska, Willburger 2014: 53-54). The corporation's office was probably located in one of the rooms within the house H1. An ostracon with the trading-administrative text found in

\footnotetext{
${ }^{9}$ Over 30 examples of identical jugs were found here during previous seasons. For other pottery deposits in latrines see: Majcherek 2008: 107; Szymańska 2010: 402; Czerner et alii 2016: 153, 158; Wilson 2011: 103 (with further references).

${ }^{10}$ The same jug types were identified during the excavations in the building S5. More on such jugs and their function in Drzymuchowska 2012: 73-76, fig. 2. In Abu Mena they were encountered in the deposits dated from 6th up to 9th century, Engemann 2016: 97.

${ }^{11}$ In the latest phase of the house H1 (dated to the first half of 8th century) we came across numerous traces of reuse of building materials..

${ }^{12}$ For identification of the building S3 see Kościuk 2012: 32.
} 
the trench S1-1 may indicate that also in this part of the town there was a similar office. Further research is of course essential to back up this hypothesis.

Exploration in the trench S1-1 proved that the building S3 was much bigger than it was first expected. Furthermore, the argument about later added eastern wing was refuted, as a result of the works carried out in the trench S3-1. Contemporary with the warehouse/shop were two newly discovered, but still enigmatic buildings S4 and S5. Nonetheless, it seems that the north-east part of 'Marea' was quite densely built-up.

To the same occupation level belongs the street located behind the Great Basilica. It was eventually narrower than first thought $($ c. $5 \mathrm{~m}$ ) and there was no paving nor sewage system. The street was straight and fitted perfectly to the overall plan of the town.

In the 7th-8th century this part of 'Marea' started to change, hence the intentional demolition or gradual destruction of walls. The rubbish dumps were the last trace of human activity in this area, which was permanently deserted around the half of 8th century.

\section{References}

Babraj, K., Drzymuchowska, A., \& Willburger, N. (2014). Marea 2011, PAM 23(1), 45-61.

Babraj, K. \& Kogut, J.P. (2015). Late-Roman and Early Bizantyne Analogues of Structures in Marea/Philoxenite, Materiały Archeologiczne 40, 87-100.

Babraj K., \& Szymańska, H. (2018). Funerary Chapel, in: Szymańska, Babraj 2008a, 177-178.

Babraj, K., Szymańska, H., Drzymuchowska, A., \& Willburger, N. (2018). Eleventh Season of Excavations at Marea (2010)" PAM 22, 55-78.

Blue, L. \& Khalil, K. (eds) (2010). Lake Mareotis: Reconstructing the Past: Proceedings of the International Conference on the Archaeology of the Mareotic Region Held at Alexandria University, Egypt, 5th-6th April 2008, (BAR IS 2274, University of Southampton Archaeological Series 2), Oxford: Archaeopress.

Czerner R., Bąkowska-Czerner, G., Grzegorek, W., \& Majcherek, G. (2016). Research and Conservation in Marina el-Alamein in 2014 and 2015 (Polish-Egyptian Conservation Mission). Part one: The Southern Bath and Central Town Square, PAM 25, 145-166.

De Groot, A. \& Bernick-Greenberg, H. (2012). Excavations at the City of David 1978-1985 Directed by Yigal Shiloh, Volume VIIA: Area E: Stratigraphy and Architecture: Text (Qedem 53), Jerusalem: Hebrew University of Jerusalem. 
Dixneuf, D. (2012). Amphores égyptiennes: Production, typologie, contenu et diffusion (III siècle avant J.-C.-IX siècle après J.-C.)(Études Alexandrines 22), Alexandrie: Centre d'Études Alexandrines.

Drzymuchowska A. (2012). Marea 2009: Pottery from the Excavations, PAM 21, 72-77.

Engemann, J. (2016). Abū Mīnā VI. Die Keramikfunde von 1965 bis 1998 (Archäologische Veröffentlichungen 111), Wiesbaden: Harrassowitz.

el-Fakharani F. (1983). Recent excavations at Marea in Egypt. In G. Grimm (Ed.), Das römischbyzantinische Ägypten: Akten des internationalen Symposions 26.-30. September 1978 in Trier (Aegyptiaca Treverensia 2)(pp. 175-186). Mainz: Zabern.

Fournet, Th., \& Redon, B. (2017). Romano-Byzantine Baths of Egypt. The Birth and Spread of a Little-Known Regional Model, In B. Redon (Ed.), Collective Baths in Egypt 2. New Discoveries and Perspectives (Études urbaines 10)(pp. 279-321). Le Caire: Institut français d'archéologie orientale du Caire.

Foy, D. (2011). Les porte-mèche des lampes en verre de l'Antiquité tardive, Provence historique 61, 207-239.

Grossmann, P. (1977). Abu Mena Achter vorläufiger Bericht. Kampagnen 1975 und 1976, MDAIK $33,35-45$.

Grossmann, P. (2002). Christliche Architektur in Ägypten (Handbook of Oriental Studies 62), Leiden, Boston, Köln: Brill.

Grossmann, P., Hölzle, W., Jaritz, H., \& Kościuk, J. (1991). Abū Mīnā 12. Vorläufiger Bericht. Kampagnen 1984-1986, AA, 457-486.

Hayes, J.W. (1972). Late Roman Pottery, London.

Jansen, G.C.M., Koloski-Ostrow, A.O., \& Moormann, E.M. (Eds) (2011). Roman Toilets. Their Archaeology and Cultural History (BABESCH Supplement 19), Leuven, Paris, Walpole: Peeters.

Koloski-Ostrow, A.O. (2011). Design, Architecture and Decoration. In: Jansen, Koloski-Ostrow, Moormann 2011, 51-63.

Kościuk, J. (2012). Preliminary Observations on Late Antique Marea Topography. In: J.L. Dobesz, A. Gryglewska, \& M.M. Rudnicka-Bogusz (Eds), Nie tylko trony: księga jubileuszowa ofiarowana Profesorowi Ernestowi Niemczykowi (pp. 29-38). Wrocław: Oficyna Wydawnicza Politechniki Wrocławskiej.

Majcherek, G. (2008). The Pottery Assemblage from the Baths and Sāqiyah. In Szymańska, Babraj 2008a, 105-127. 
Pichot, V. (2010). Marea Peninsula: Occupation and Workshop Activities on the Shores of Lake Mariout in the Work of the Center d'Études Alexandrines (CEAles, CNRS USR 3134). In Blue, Khalil 2010, 57-66.

Pieri, D. (2005) Le commerce du vin oriental à l'époque byzantine (Ve-VII siècles). Le témoignage des amphores en Gaule (Bibliothèque Archéologique et Historique 174). Beirut : Institut français du Proche-Orient.

Rodziewicz, M. (2010). On Interpretation of Archaeological Evidence Concerning Marea and Philoxenite. In Blue, Khalil 2010, 67-74.

Szymańska, H. (2010). Report on the Activities of the Polish Archaeological Mission at Marea in 2007. ASAE 84, 401-409.

Szymańska, H., \& Babraj, K. (2007). Marea. Sixth Season of Excavations. PAM 17, 55-66.

Szymańska, H., \& Babraj, K. (2008a). Marea vol. 1. Byzantine Marea Excavations in 2000-2003 and 2006 (Biblioteka Muzeum Archeologicznego w Krakowie IV). Kraków: Muzeum Archeologiczne.

Szymańska, H., \& Babraj, K. (2008b). Baths. In Szymańska, Babraj 2008a, 27-84.

Wilson A. (2011). Urination and Defecation Roman-Style. In Jansen, Koloski-Ostrow, Moormann 2011, 95-111.

Wielgosz-Rondolino, D., \& Gwiazda, M. (2016). Marea Season 2014: Excavation in House H1. PAM 25, 115-126.

Wipszycka, E. (2012). Marea and Philoxenite. Where to Locate Them?. ET 25, 417-432.

\section{Abbrevations}

AA - Archäologischer Anzeiger

ASAE - Annales du Service des Antiquités de l’Égypte

BAR IS - British Archaeological Reports, International Series

ET - Études et Travaux

MDAIK - Mitteilungen des Deutschen Archäologischen Instituts, Abteilung Kairo

PAM

\section{Capitations}

Fig. 1. Plan of promontory with marked trenches of 2018 excavations (M. Gwiazda after, J. Kogut, D. Tarara, J. Kościuk, A. Kutiak). 
Fig. 2. West side view on the collapsed wall of the building S3 (Photo A. Pawlikowska-Gwiazda). Fig. 3. Ortophoto plan of trench S1-1 (Photo M. Gwiazda).

Fig. 4. South side view on the mudbrick wall ruins in the trench S1-1 Photo (A. PawlikowskaGwiazda).

Fig. 5. Ortophoto plan of the trench S1-2 (Photo M. Gwiazda).

Fig. 6. Board game found on the street behind the Great Basilica (A. Pawlikowska-Gwiazda).

Fig. 7. East side view on the street between the Great Basilica and the building S3 (Photo A. Pawlikowska-Gwiazda).

Fig. 8. Ortophoto of the pavement in the room S3-1 (Photo M.Gwiazda).

Fig. 9. Northern trench section in the room S3-1 (Drawing M. Gwiazda).

Fig. 10. Ortophoto plan of the building S4 (Photo M. Gwiazda).

Fig. 11. Ortophoto plan of the building S5 (Photo M. Gwiazda).

Fig. 12. Ortophoto plan of the latrine L1 (Photo M. Gwiazda).

Fig. 13. Selected jugs discovered inside the sewers in the latrine L1 (Drawing. J. Faucher, digitalisation M. Gwiazda). 



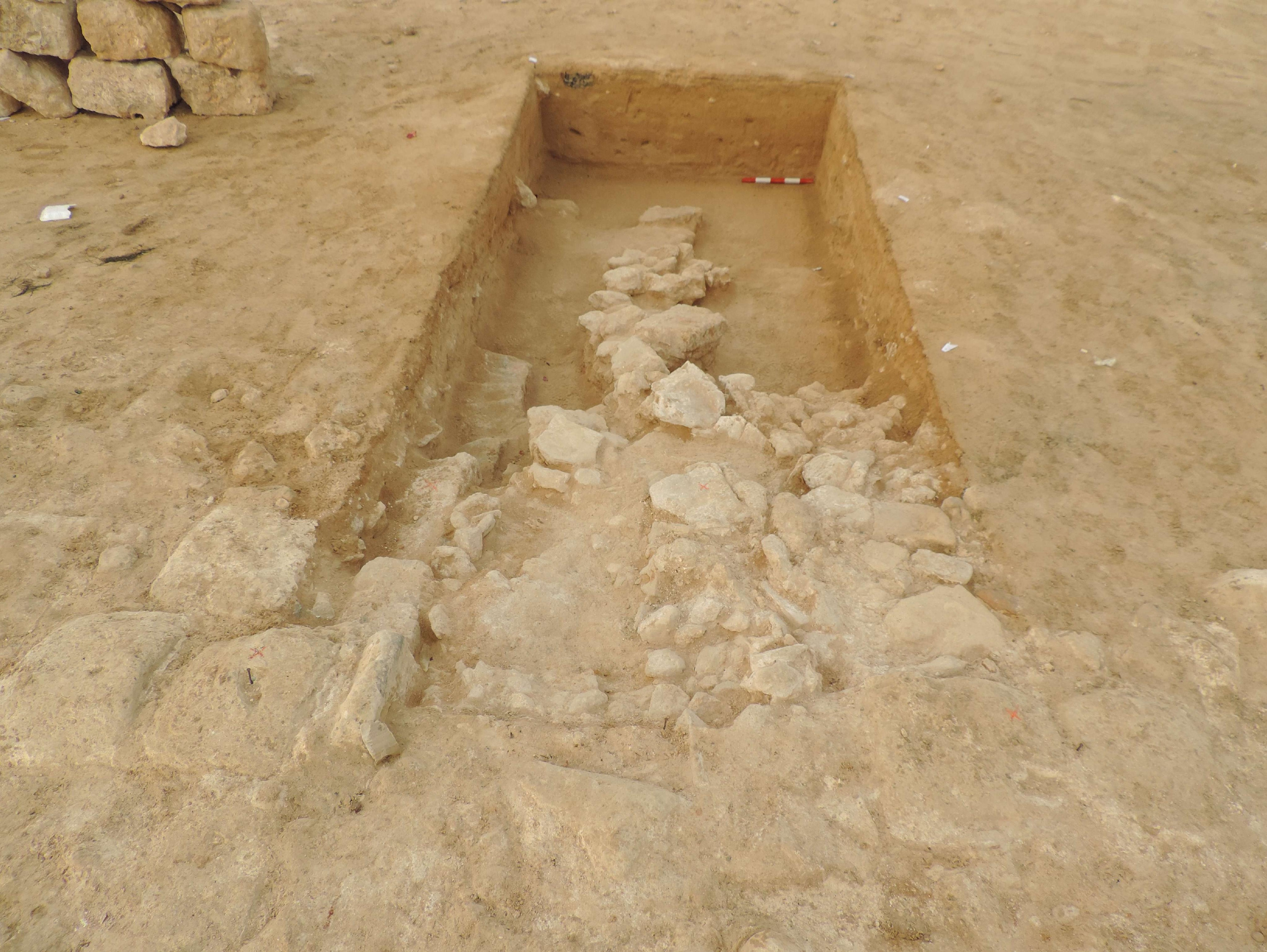




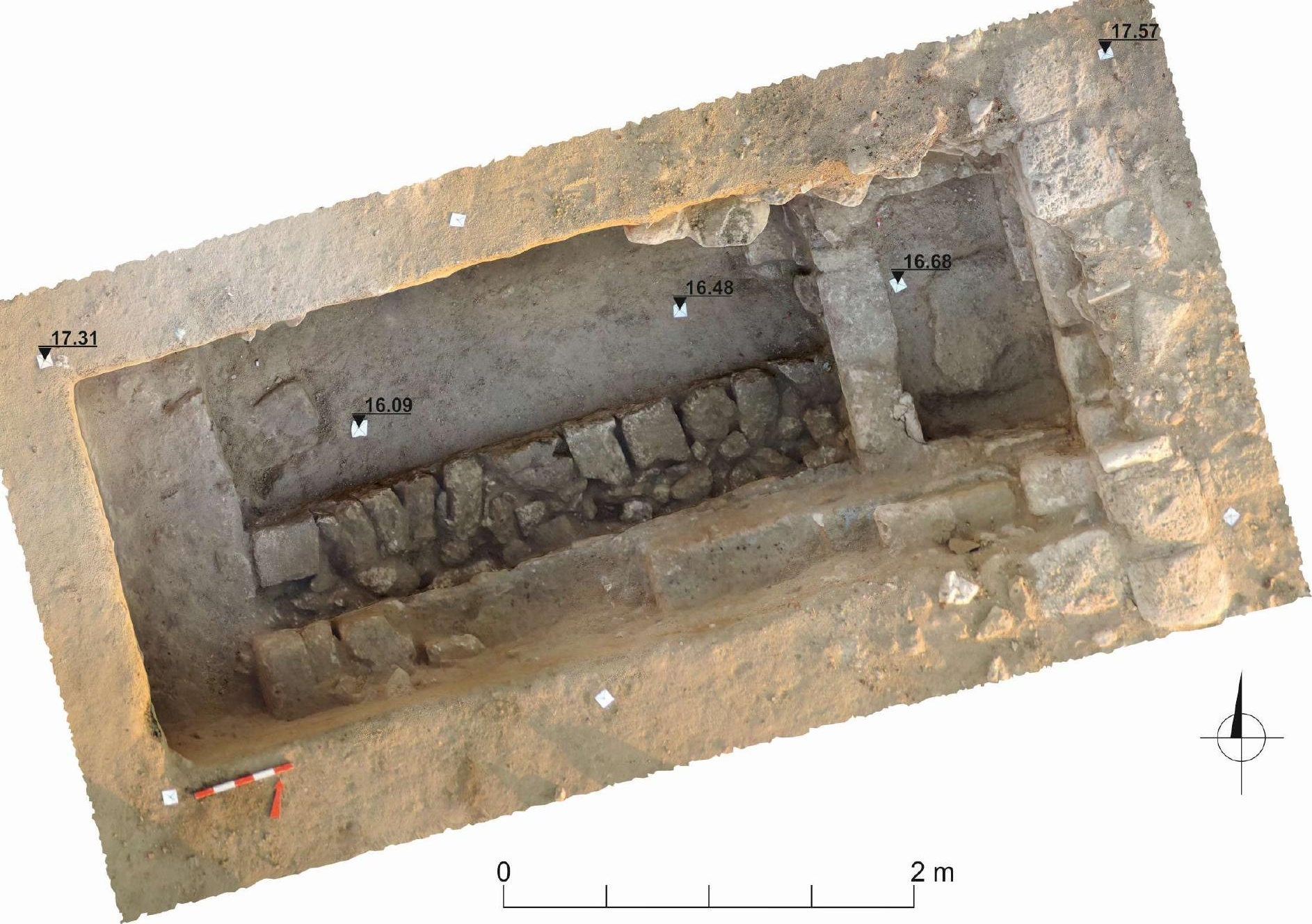









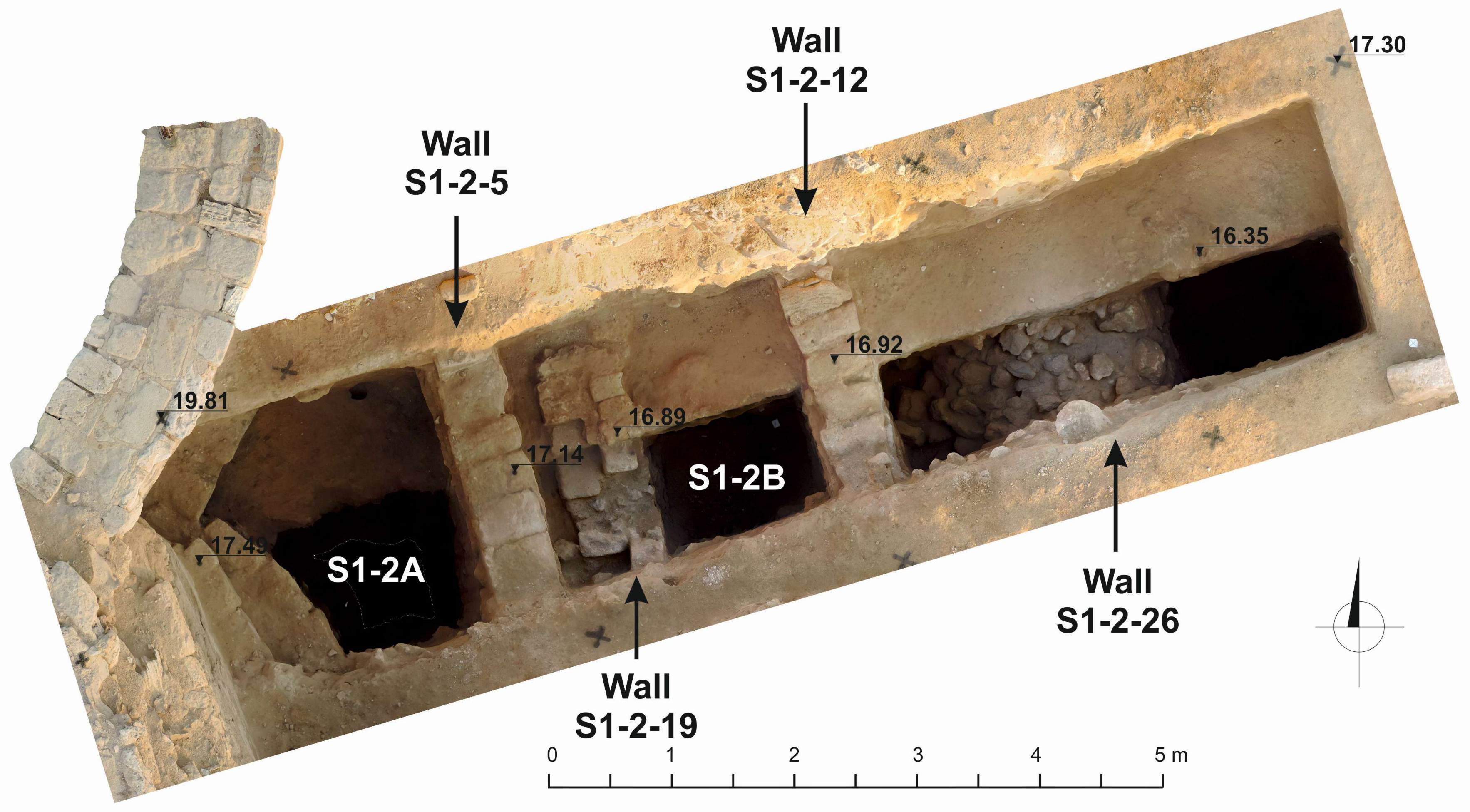




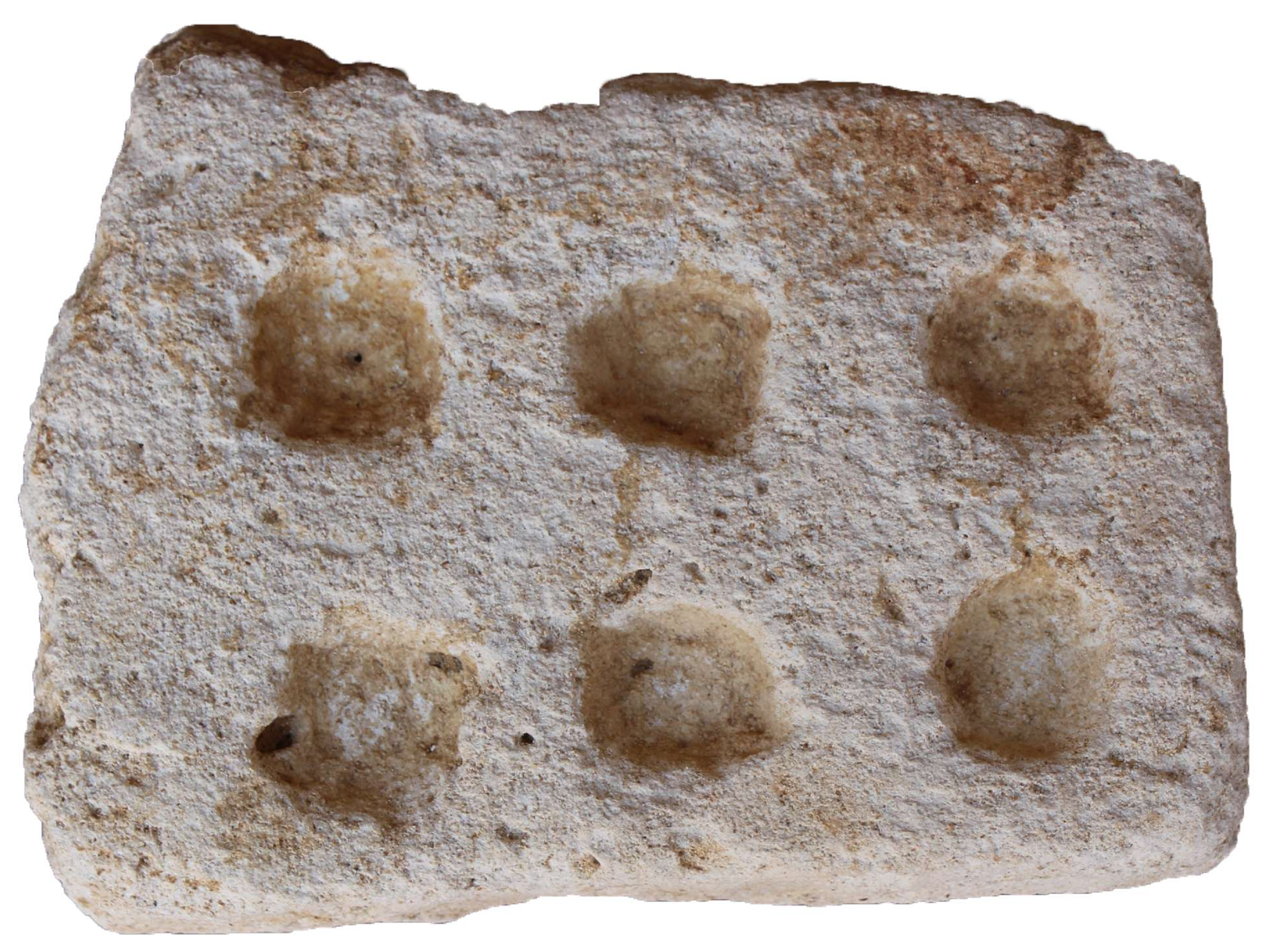

0

$20 \mathrm{~cm}$

$1 \quad 1 \quad 1$ 


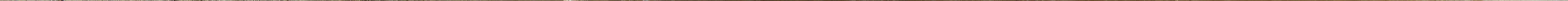




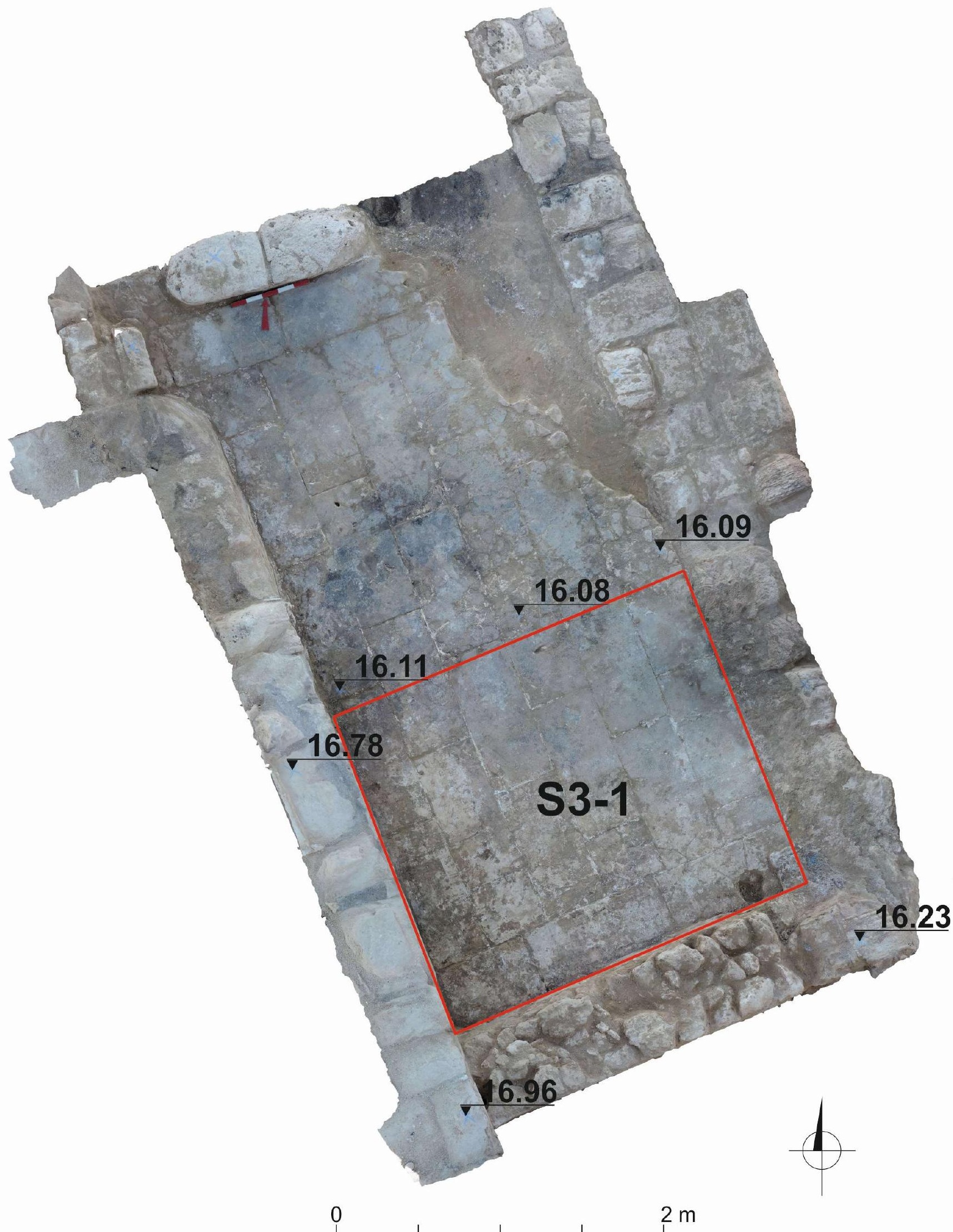




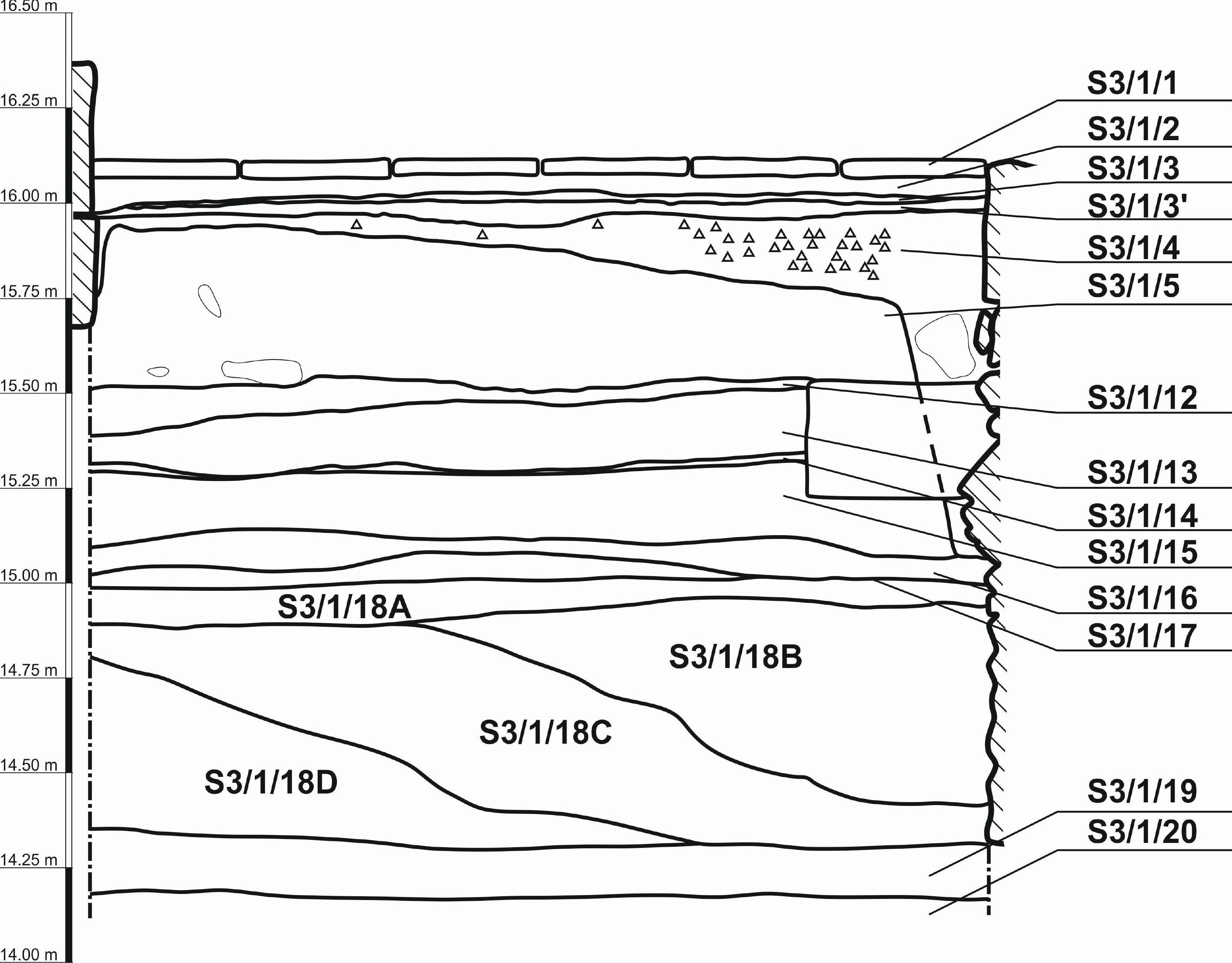




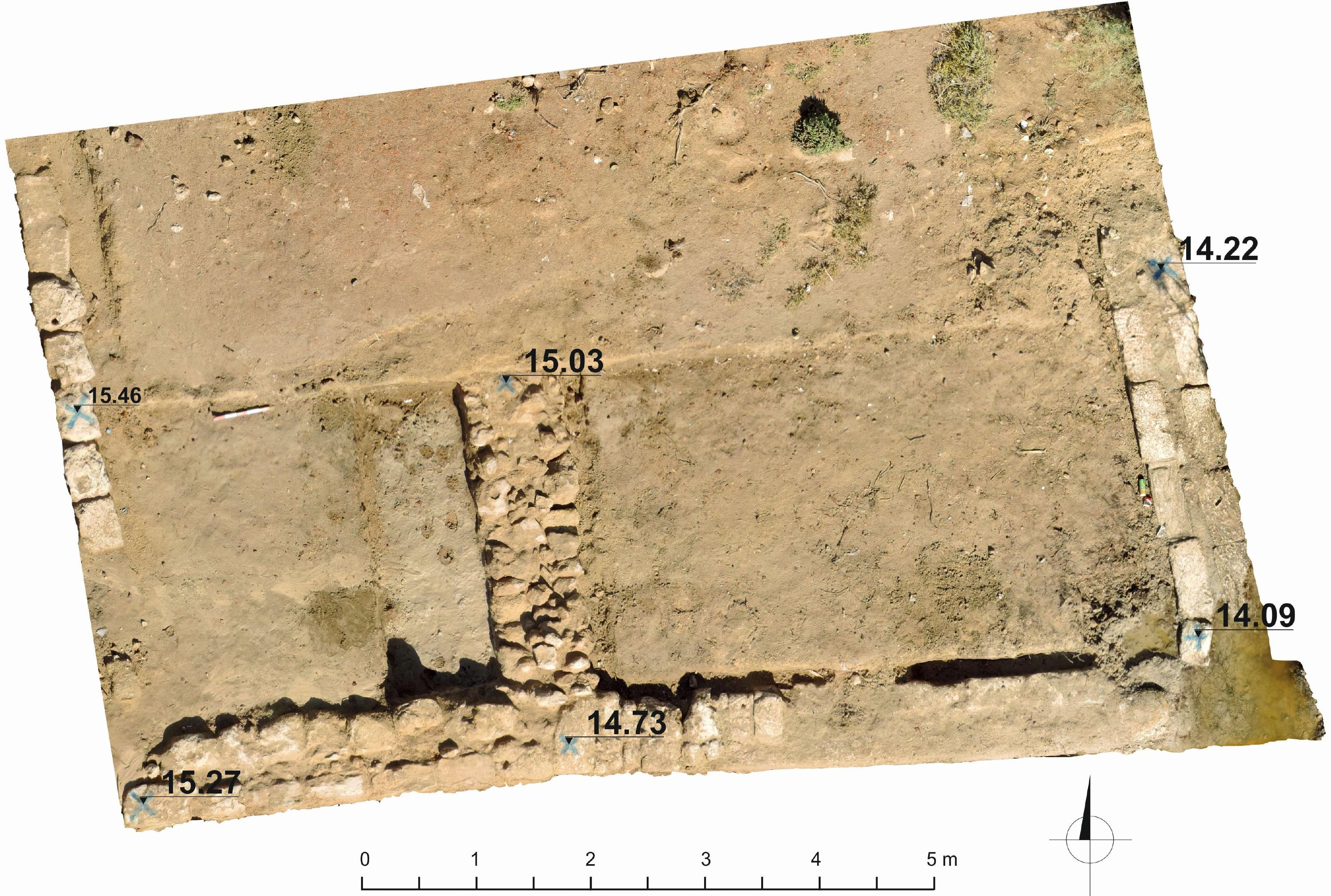




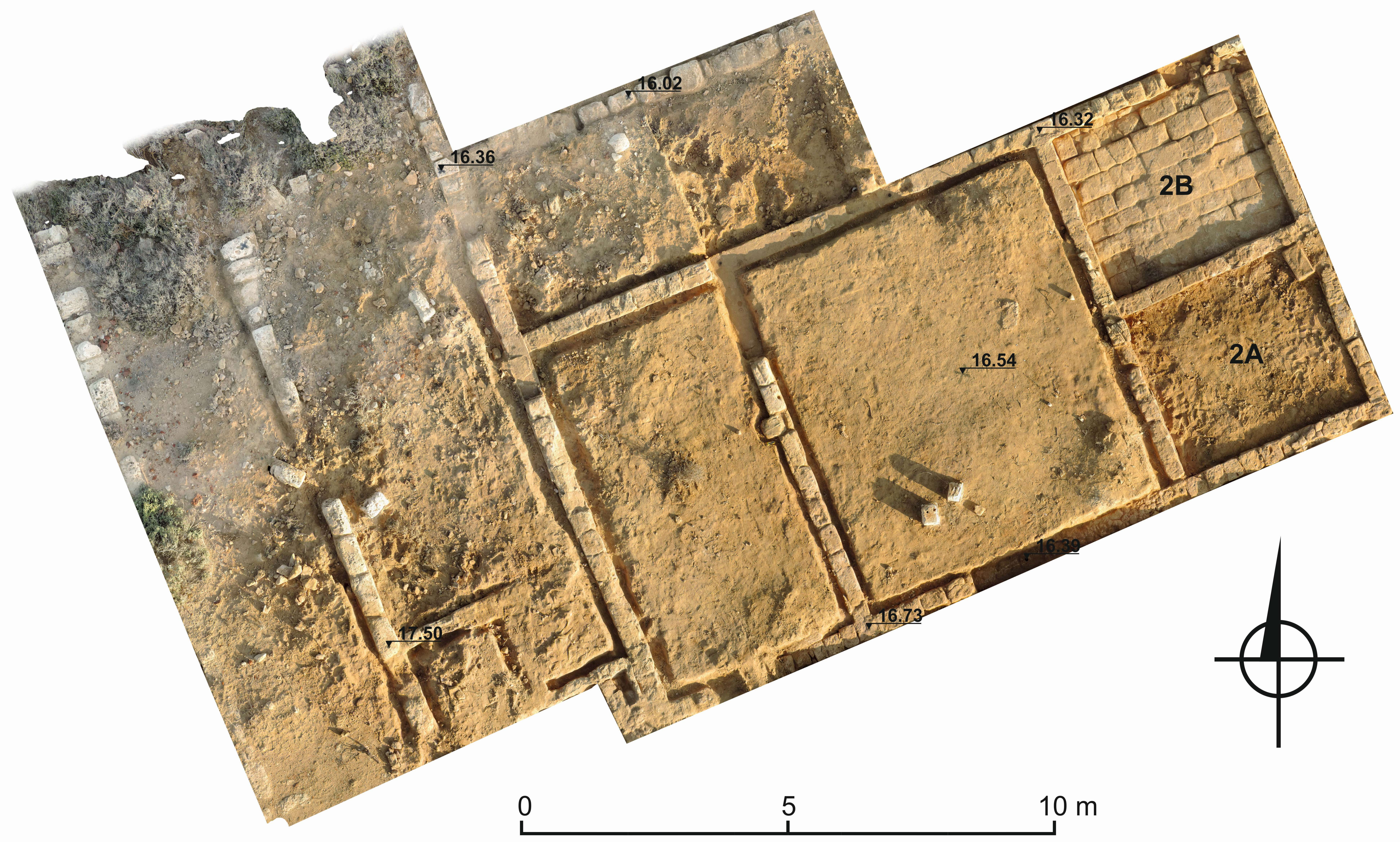




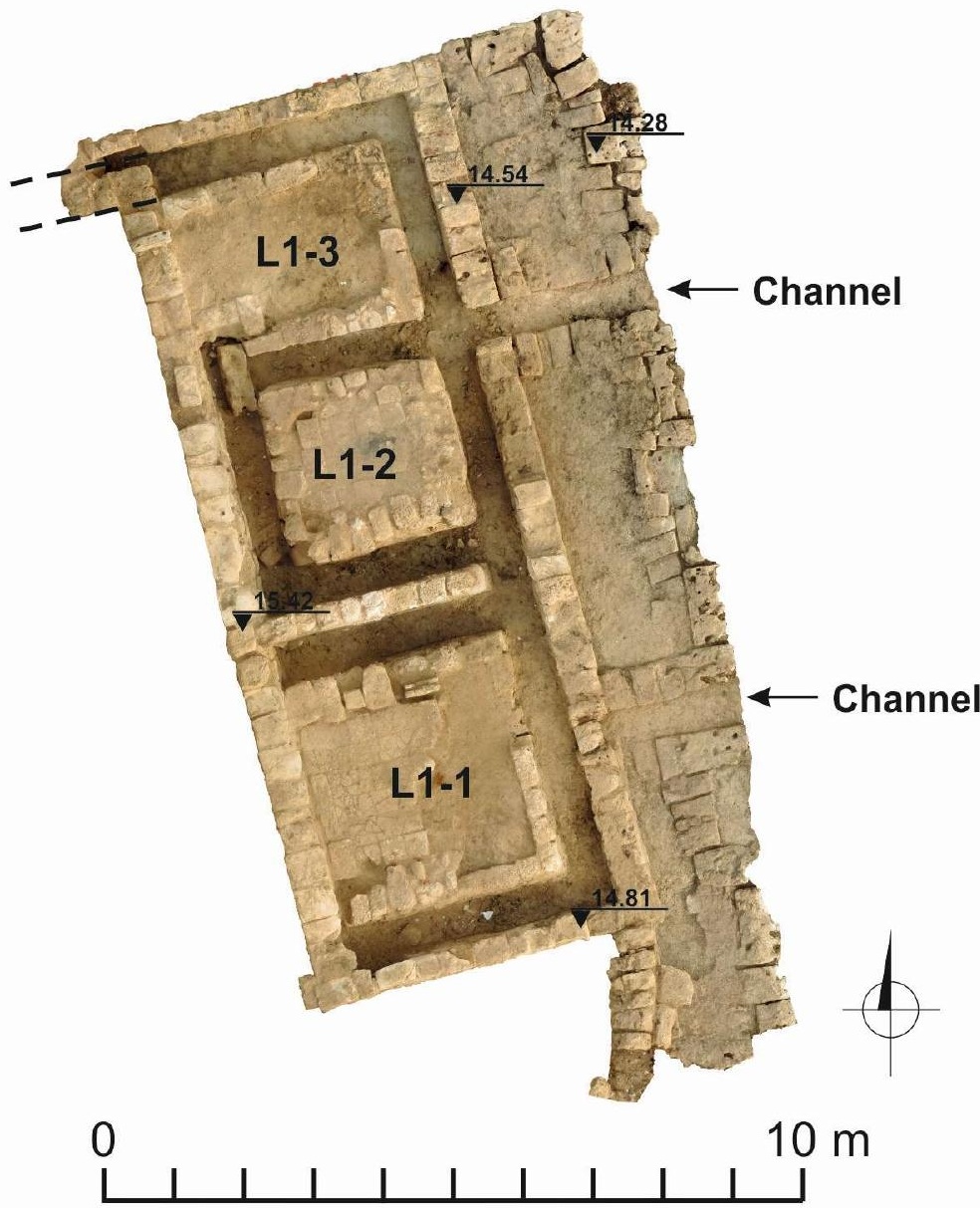



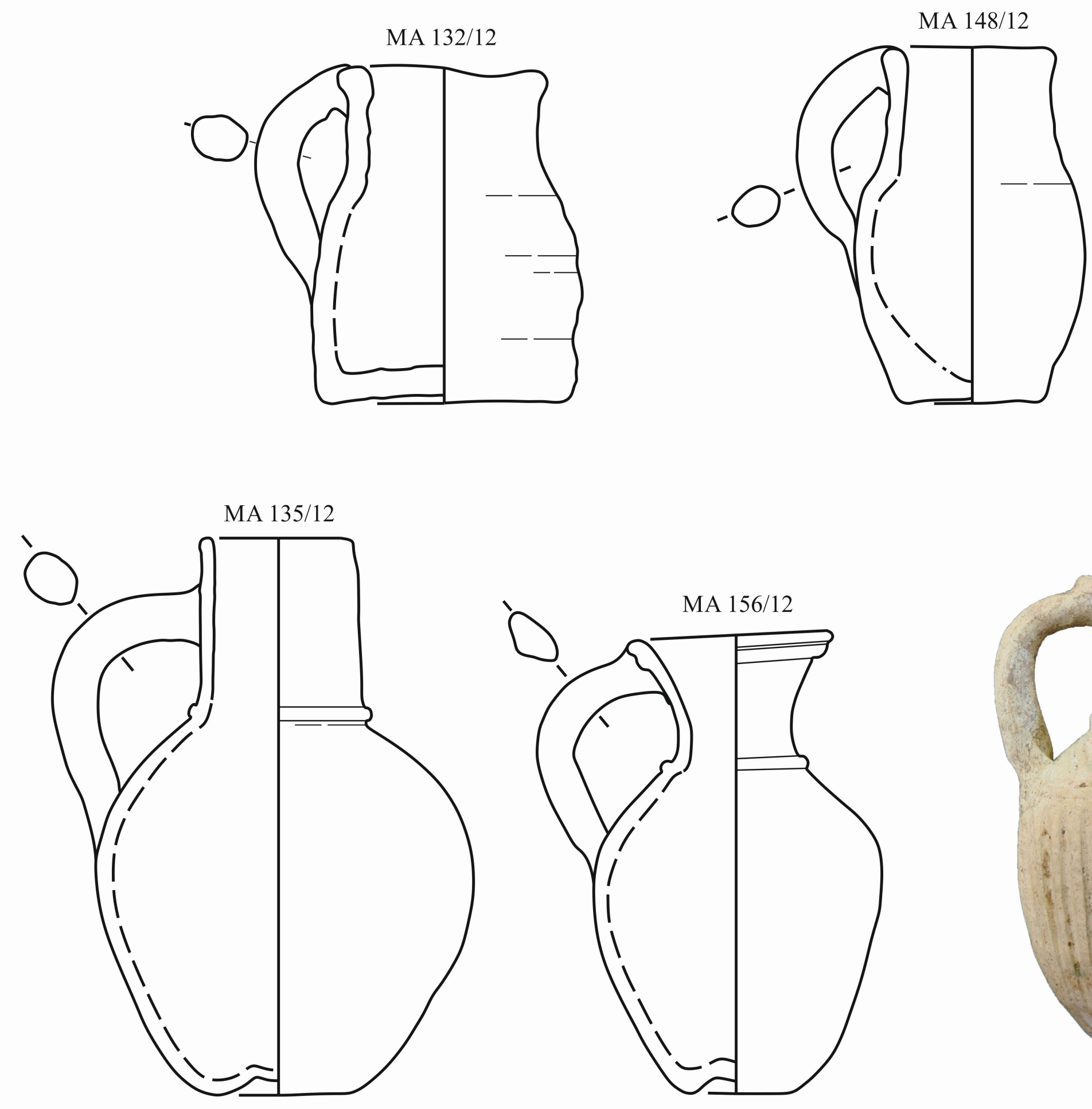

MA $126 / 12$ 